\title{
Distribution patterns and relationship between elevation and the abundance of Aedes aegypti in Mojokerto city 2012
}

\author{
Zulfaidah Penata Gama ${ }^{1,2^{\star}}$, Nobukazu Nakagoshi ${ }^{1}$, Madaniatul Islamiyah $^{2}$ \\ ${ }^{1}$ Graduate School for International Development and Cooperation (IDEC), Hiroshima University, Kagamiyama, Japan; \\ *Corresponding Author: zulfaidahpenatagama@gmail.com \\ ${ }^{2}$ Department of Biology, Faculty of Science, Brawijaya University, Malang, Indonesia
}

Received 30 July 2013; revised 2 September 2013; accepted 22 September 2013

Copyright (C) 2013 Zulfaidah Penata Gama et al. This is an open access article distributed under the Creative Commons Attribution License, which permits unrestricted use, distribution, and reproduction in any medium, provided the original work is properly cited.

\begin{abstract}
Mosquitoes are one of the insects that have an important role as vectors of disease agents. The diseases transmitted by mosquitoes are still public health problems in Indonesia especially in East Java Province, for example, Dengue Hemorrhagic Fever (DHF). DHF is a very alarming disease because the occurrence of this epidemic is no longer just confined to certain geographic locations. At present, Mojokerto is a district in East Java region known as endemic for DHF in Indonesia. The number of cases in this district tends to rise and expand distributed. The spread pattern of dengue cases in this district is not certainly known. The aim of this research is to determine the distribution pattern of mosquitoes and its relationship between elevation and density of Aedes aegypti in the Mojokerto district that caused dengue virus transmission. Sampling was conducted at two locations in the Mojokerto district, in the urban and rural, namely Prajurit Kulon for urban and Dlanggu for rural. We used survey for mosquito larvae by WHO standard and for mosquito eggs by ovitrap. The coordinates of sampling locations are recorded using GPS and then identification of mosquitoes is performed at the Laboratory of Ecology and Animal Diversity, University of Brawijaya. Quantitative data were analyzed to determine the abundance, relative abundance, frequency, relative frequency and IVI (Importance Value Index). Mosquito distribution patterns were analyzed with Morisita index. The research findings indicated that there are five mosquitoes species consisted of Aedes aegypti, Aedes al-
\end{abstract}

bopictus, Aedes laniger, Culex bitaeniorchynchus and Culex quinquefasciatus. Aedes aegypti is the dominant species in urban area while Culex quinquefasciatus is the dominant species in rural area. Morisita index showed that mosquito dispersal on patterns in Mojokerto district is uniform. The elevation of the area and density of Aedes aegypti has a positive correlation.

Keywords: Aedes aegypti; Distribution Pattern; Elevation; Mojokerto

\section{INTRODUCTION}

Dengue hemorrhagic fever is one of the most important viral diseases in the world. Dengue viruses are among the most widely distributed and significant arthropod-borne viruses (Arboviruses) affecting humans. DHF potentially affects 2.5 billion people and more than 100 tropical and sub-tropical regions of the world $[1,2]$. Dengue is one of the most serious health problems in Indonesia, with Aedes aegypti acting as the vector [3]. DHF outbreaks have been recorded in Surabaya area since 1986. DHF virus is transmitted to human through the bites of infective female Aedes sp. (Diptera: Culicidae) mosquitoes [4].

Aedes aegypti often breeds in water storage containers used by households without tap water supply and occurs in high numbers even in dense urban areas [5]. These mosquitoes are well adapted to the urban environment and successfully breed in containers where water is allowed to accumulate, such as discarded can, bottles, plastic containers, and tires. Aedes aegypti is particularly susceptible to climate variability and climatic change. Changes in mean climate conditions and climate variability also can affect human health via indirect pathways, 
especially in the changing of biological and ecological processes that influence infectious disease transmission and food yields [6].

Global emergence and resurgence of dengue can be attributed to multiple factors including urbanization, transportation and changes in human migration and behavior, resulting in dengue increase as the second most important vector-borne disease, after malaria, in term of human morbidity and mortality [2]. It also occurred in East Java, since it has been discovered in Surabaya, and the number of cases tends to rise and expand in distribution. This condition is closely related to the increased mobility of the population in line with the fluent transport links and the spread of dengue virus and mosquitoes in various regions in Indonesia [7]. Environmental circumstance strongly controls the geographic distribution and abundance of Aedes aegypti.

Mojokerto is one of the cities in East Java that has endemic DHF. Based on the DHF case incidence data from 2008 to 2010, it was obtained from P2PL of DHF. Health Department of East Java Province showed that Mojokerto district still had House Indices (HI), Containers Indices (CI), and Breteau Indices (BI) quite high at 35\%, $27.3 \%$ and $42.86 \%$ respectively [8]. Therefore, the ob- servation was undertaken to determine the distribution pattern of Aedes aegypti and risk factors of DHF between regency and cities in Mojokerto 2012 and correlation between elevation of sampling location and distribution of mosquito.

\section{MATERIALS AND METHODS}

\subsection{Study Area}

Mojokerto District is located between $112^{\circ} 26^{\prime} 01^{\prime \prime}$ East longitude and $7^{\circ} 27^{\prime} 59^{\prime \prime}$ South latitude in East Java Province (see in Figure 1). Mojokerto's territory is 872 km², located between $15 \mathrm{~m}$ and $3156 \mathrm{~m}$ above sea level. The Brantas River divided it into north and south regions. The district shares the boundary with Gresik and Lamongan district in the north, with Malang district in the south, with Sidoarjo and Pasuruan in the east, and with Jombang distrist in the west. South Region has several mountains, which includes Welirang Mountain (3156 m), Anjasmoro Mountain (2277 m) and Penanggungan Mountain (1693 m). Based on BPS [9] showed that the population of the district is about $1,014,785$. Many of them earn their living as small farmers and craftsmen (consisting shoemakers, furniture makers, and souvenir

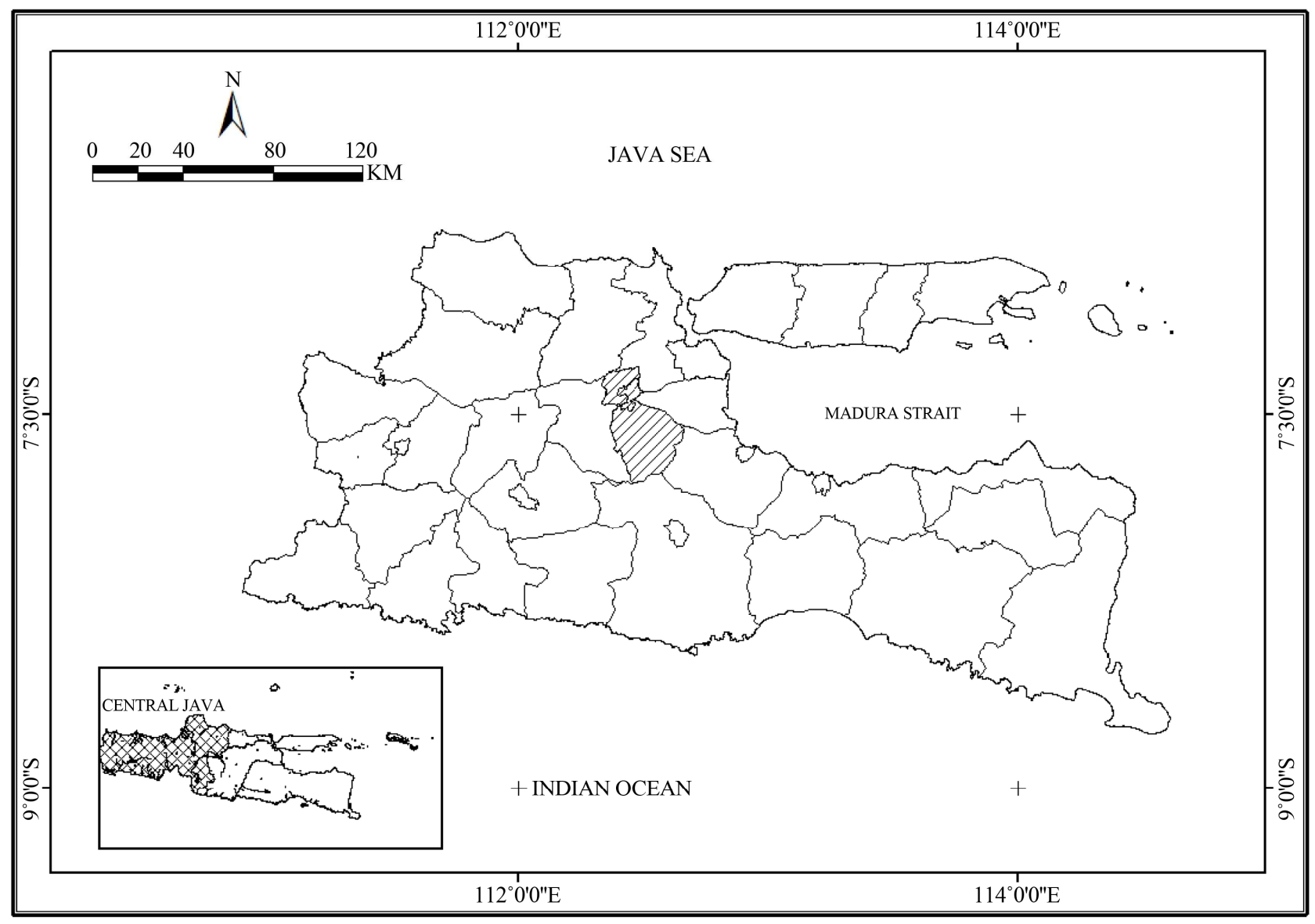

Figure 1. Study site. 
makers). This area was selected as the study site based on the results of the previous research that it was the one of major DHF epidemic foci in Indonesia. The DHF incidence was recorded at the district level (lattice data).

\subsection{Data Collection}

Sampling was carried out in urban and rural area of Mojokerto District. Selected area of the urban is Prajurit Kulon while the selected rural is Dlanggu. Each area was taken three villages, namely are Surodinawan, Blooto, Kranggan villages for urban and Mojokarang, Segunung, Kalen for rural. Each village location in the five-point set was sampled.

\subsection{Capturing Larvae of Mosquito}

Random coordinates were selected for five sampling points in each village site using a topographical map broken into $1-\mathrm{m}^{2}$ grid squares. Coordinates were reselected if they fell inside inaccessible areas (e.g., in the middle of ponds), or inside unsecured areas (e.g., on public roads), or there were located within $30 \mathrm{~m}$ of other coordinate [10]. Larval sampling method with a dipper from various places such as mosquito breeding places in the house that shelters consisting of a water bath tubs, tubs toilets, drinking water containers, jars, bowl of water, and a bucket. Mosquito breeding places outside the home such as drums, cans, bottles, pot scrap decorative plant pots filled with rainwater. Observation of the presence or absence of mosquito larvae was carried out for 4 days.

\subsection{Capturing Egg of Mosquito}

The capture of the eggs laid by the mosquito is collected in a plastic cup that was given water. The ovitrap was placed on each house is only one piece. Ovitrap discarded and replaced by new water when sampling egg of mosquito are conducted in each location. The number of eggs were calculated after they hatched become mosquito larvae.

\subsection{Statistical Analysis}

Data analysis was performed to test the correlation between elevations of each sampling location and the number of mosquitoes in Mojokerto District.

Determining the Importance Value Index (IVI)

Important Value Index (IVI) is used to establish the dominance of a species to other species or in other words the importance of describing the position of a species in the ecological community. Calculate Frequency, Abundance, Relative Frequency and Relative Abundance, analysis using Microsoft Excel 2007. IVI (Importance Value Index) can be determined by:

$$
\text { IVI = Relative Abundance }+ \text { Relative Frequency }
$$

\subsection{Determination of Population Distribution by Morisita Index}

The distribution pattern of population can be determined by using the Morisita index by the following formula:

$$
\frac{\sum_{i=1} X_{i}^{2}-N}{N(N-1)} I d=n
$$

$N=$ total number of individual in the plot

$n=$ number of plots

$X_{i}^{2}=$ the square of the number of individuals in the plot to $I$ [11]

Morisita index is a statistical measure of dispersion of individuals in a population. It is used to compare overlap among samples [8]. This formula is based on the assumption that increasing the size of the samples will increase the diversity because it will include different habitats (i.e. different faunas). The standardized Morisita index was used to assess the spatial pattern (i.e. clumped, random or uniform) of the most abundant species. The index was calculated as:

Values of $I d=1$ indicate a random dispersion Values of $I d<1$ indicate a uniform dispersion Values of $I d>1$ indicate a clumped dispersion

\section{RESULTS}

Mosquitoes were found in Mojokerto district consist of five species: were Aedes aegypti, Aedes albopictus, Aedes laniger, Culex bitaeniorchynchus and Culex quinquefasciatus.

Table 1 showed that mosquitos larvae in the urban area (Prajurit Kulon) were encountered are Aedes aegypti, Aedes albopictus and Culex quinquefasciatus. Aedes aegypti is the dominant species as the highest IVI value.

The capturing egg of mosquitos using ovitrap in Kulon Prajurit (the urban area) showed that it found three types of mosquitoes. These species are Aedes aegypti, Aedes albopictus and Culex quinquefasciatus (see in Table 2).

Pearson correlation was conducted in Mojokerto District, 2012 related to elevation of each area to the density

Table 1. Mosquito larval abundance and composition in Mojokerto district.

\begin{tabular}{ccc}
\hline \multirow{2}{*}{ Species } & \multicolumn{2}{c}{ Abundance (individu) } \\
\cline { 2 - 3 } & Urban & Rural \\
\hline Aedes aegypti & 52 & 50 \\
Aedes albopictus & 49 & 62 \\
Aedes laniger & - & 7 \\
Culex bitaeniorchynchus & - & 48 \\
Culex quinquefasciatus & 39 & 104 \\
\hline
\end{tabular}


Table 2. Abundance and composition of mosquitoes were captured with ovitrap.

\begin{tabular}{ccc}
\hline \multirow{2}{*}{ Species } & \multicolumn{2}{c}{ Abundance (individu) } \\
\cline { 2 - 3 } & Urban & Rural \\
\hline Aedes aegypti & 54 & 55 \\
Aedes albopictus & 20 & 22 \\
Culex quinquefasciatus & 50 & 99 \\
\hline
\end{tabular}

of Aedes aegypti measures. The results showed that elevation of the area and density of Aedes aegypti has a positive association (see Table 3 ).

Figure 2 illustrates that Aedes aegypti with Importance Value Index (IVI) of $70.48 \%$ followed by Aedes albopictus (68.33\%) and Culex quinquefasciatus (61.19\%). Aedes aegypti is more often found in urban areas (Prajurit Kulon) than rural area (Dlanggu Subdistrict). There is also a similar result on the previous studies stated that Aedes aegypti is more dominant than Aedes albopictus [12].

Species of mosquitoes were found in the Dlanggu subdistrict illustrated in Figure 3, they are Aedes aegypti, Aedes albopictus, Aedes laniger, Culex bitaeniorynchus, Culex quequinfasciatus. Culex quinquefasciatus has the highest IVI value (59.8\%) than other species, and there is followed by Aedes albopictus (44.31\%), Aedes aegypti (39.88\%), Culex bitaeniorynchus (39.14\%), Aedes laniger (16.87\%).

The dominant species of mosquito's larvae in Prajurit Kulon is Aedes aegypti as illustrated in Figure 4, it has Importance Value Index (IVI) of $76.88 \%$ followed by 73.66\% for Culex quinquefasciatus and Aedes albopictus amounted to $49.46 \%$.

Based on the capturing mosquitoes using ovitrap in Mojokerto (the rural area) were found that three mosquitoes species namely, Aedes aegypti, Aedes albopictus, and Culex quinquefasciatus. Figure $\mathbf{5}$ illustrates the dominant species is the Culex quinquefasciatus with Importance Value Index (IVI) of $89.58 \%$, followed by Aedes aegypti (64.58\%) and Aedes albopictus (45.83\%).

\section{DISCUSSION}

Data of Health Department of Mojokerto District (2012) showed that outbreak of DHF were still suffering highly in this region. The occurrence of DHF outbreaks is linked to a number of factors, including the density of mosquito vectors particularly that of Aedes aegypti. The precise population density of Aedes aegypti is needed to sustain dengue virus transmission epidemically or endemically has yet to be determined, but experience in Nganjuk during the past 3 years from 2008 to 2010 suggest that house indices as low as $30 \%$ are sufficient for

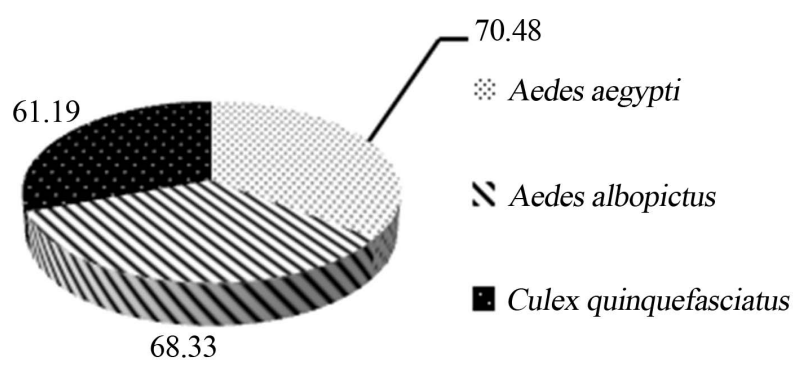

Figure 2. Important value index (\%) of mosquitoes larvae in Prajurit Kulon.

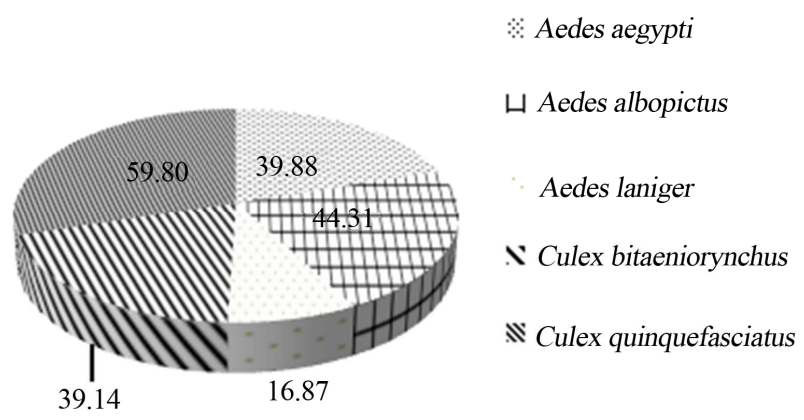

Figure 3. Important value index (\%) of mosquitoes larvae in Dlanggu.

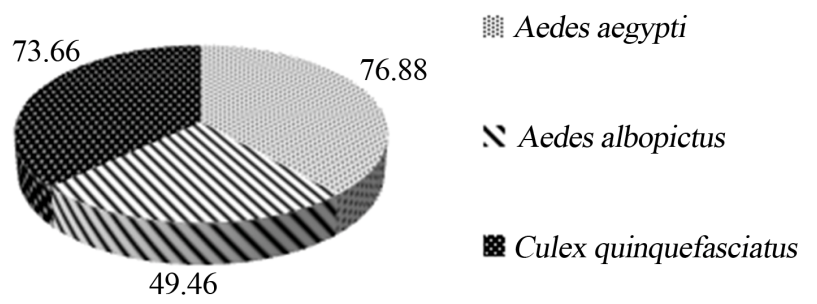

Figure 4. Important value index (\%) of mosquitoes larvae in Prajurit Kulon (captured with ovitrap).

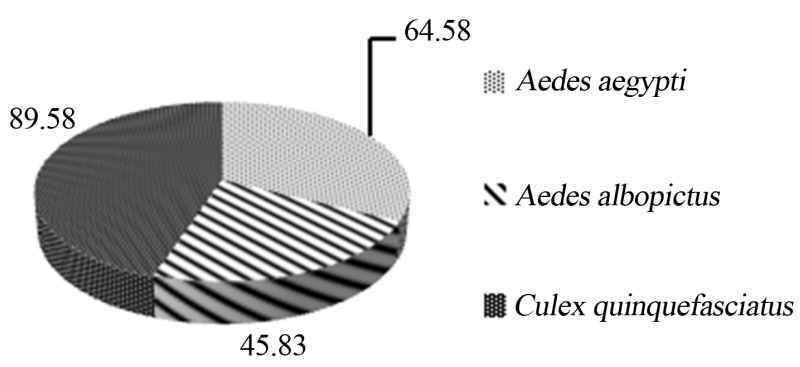

Figure 5. Important value index (\%) of mosquito's larvae in Dlanggu (captured with ovitrap).

the epidemic transmission of dengue in area where there is a low level of immunity in the human population. In many instances, a small number of actively biting female mosquitoes has infected an entire household. Denser human population increases virus transmission. Urbanization in tropical countries has resulted in both a proliferation of Aedes aegypti and an increase in the number of susceptible human host [13]. In the urban area (for ex- 
Table 3. Pearson correlation between elevation of each location and the density of Aedes aegypti in Mojokerto district.

\begin{tabular}{cccc}
\hline & & Elevation & Aedes aegypti \\
\hline Elevation & Pearson correlation & 1 & $0.418^{*}$ \\
& Sig. (2-tailed) & & 0.022 \\
& $\mathrm{~N}$ & 30 & 30 \\
Aedes aegypti & Pearson correlation & $0.418^{*}$ & 1 \\
& Sig. (2-tailed) & 0.022 & \\
& $\mathrm{~N}$ & 30 & 30 \\
\hline
\end{tabular}

${ }^{*}$ Correlation is significant at the 0.05 level (2-tailed).

ample: Prajurit Kulon), the movement of viraemic persons is a more important means of transporting dengue viruses than the movement of Aedes aegypti mosquitoes. Place where people congregate during the day has important sites of dengue virus transmission. Dengue virus may also spread in settings related to large numbers of people such as in hospitals where visitors, patients, and staffs maybe bitten by infected Aedes aegypti.

Some of other factors that also influence DHF outbreaks are the behavior of female mosquitoes to lay their eggs. Various factors that caused a lot of Aedes and Culex larvae are found in the surrounding Dlanggu (the rural area in Mojokerto district) including residential areas, shrubs (vegetation) lush, plantation, cattle sheds, gutters, and along the river. Based on the survey in this rural showed that Culex quinquefasciatus is being the dominant species. This is in contrast with previous research; it stated that Culex quinquefasciatus is a species commonly found in urban residential areas.

Aedes aegypti is the predominant species in urban areas due to the location of housing coincide thus increasing mosquito breeding. Density of eggs/larvae of mosquitoes in the container is influenced by the type, color and ability to absorb water containers. Smooth-walled containers light and does not absorb water, as it is owned by ovitrap glass, relatively less favored by mosquitoes. Smooth surface will make it difficult for laying ovum of mosquito.

Culex quinquefasciatus is the dominant species due to the condition of the house adjacent to the yard there are trees and grass. Around the site there are also stagnant and dirty water sewers, which are potential sites for Culex mosquitoes breeding. In addition, there are also some standing water mosquitoes, either rainwater or water reservoirs households that are not covered. Mosquito larvae are generally found in various places such as aquatic ponds, artificial containers, and trees holes in the other pool. Development of mosquito larvae is influenced by abiotic factors, especially temperature. Optimal temperature in media ranges from breeding places is $25^{\circ} \mathrm{C}-27^{\circ} \mathrm{C}$. Based on temperature data obtained from BMKG [14] showed that the average temperature in the area of Mojokerto District reach $27^{\circ} \mathrm{C}$ on January, so it can be said that immature mosquitoes experiencing normal growth process [4].

\subsection{The Distribution Pattern of Mosquitoes in Mojokerto District 2012}

Based on calculations using the Morisita index, it was noted that the distribution pattern of mosquitoes in the Mojokerto district is uniform. Mosquitoes have a uniform distribution due to environmental factors such as temperature and humidity at that location is not much different among each site. There are a variety of physical environments that may affect the distribution of mosquitoes, such as home layout, type of container, altitude/ elevation and climate. Presence or absence of mosquitoes in residential greatly influenced by the infrastructure of the house itself. The home construction, home wall color and arrangement of goods inside the home are also deeply affected to determine the home being liked or not by mosquitoes. Types of containers, including the location of containers, container material, container shape, containers color, the volume of water, cover the container, and the origin of water in the container are also influenced in the selection of female mosquitoes for laying their eggs.

One of the models to determine the distribution pattern of mosquitoes existing in a location is morisita index. It is useful to know the potential areas that are estimated to have high mosquito populations. Regions with high mosquito populations have the potential to contract the disease. Spread of mosquito species in Indonesia came from cities to cities, including the villages, due to transportation venues carrying rainwater as drums, cans, old tires, and other items containing larvae mosquitoes. The spread of the mosquito population is also closely related to the development of human settlements due to the establishment of the new homes are equipped with a means of procuring water for daily use.

\subsection{Relationship between Elevation and the Abundance of Aedes aegypti in Mojokerto District 2012}

In general, there were few species per site with increasing altitude. The areas at lowest elevation produced the greatest number of species but they did not produce a corresponding greater number of specimens. A decreasing number of mosquito species at the higher elevation has already been reported [15]. Another studies argued that the larger number of mosquito species collected at lower elevation might be due to increased human disruption in those areas. There is a similarity between the pre- 
sent findings and those already made in respect of species number, which remained relatively constant for the first $800 \mathrm{~m}$ from the lowest level, followed by a decrease. There are a number of views about the increased diversity at lower altitudes but the possible explanation could be the availability of favorable breeding places and preferred host. Another cause may be related to dispersal of mosquito, since they have to stop while flying to refuel with blood/nectar. Further, the tropical zone ranging between 300 and $900 \mathrm{~m}$ has the maximum temperature $27.2^{\circ} \mathrm{C}-29.4^{\circ} \mathrm{C}$ during June while the lowest $\left(11.1^{\circ} \mathrm{C}\right.$ $13.3^{\circ} \mathrm{C}$ ) in the month of January. As the optimal range of temperature for the best survival of mosquito is from $22^{\circ} \mathrm{C}$ to $31^{\circ} \mathrm{C}$, hence in the present study the diversity is more between 500 and $900 \mathrm{~m}$. A slight variation in the distribution and abundance of most of the mosquito species during the study period could be the result of several interacting climatic factors, which depend on the severity of the amount and duration of rain in the rain season. As these conditions fluctuate season-to-season and place-toplace, henceforth, restriction in elevation distribution is a result of habitat specificity. Another possible explanation is that the elevation may limit niche availability, which results in differential distribution pattern [15].

\section{CONCLUSION}

Mosquitoes found in Mojokerto region consist of five species, namely Aedes aegypti, Aedes albopictus, Aedes laniger, Culex bitaeniorchynchus and Culex quinquefasciatus. Although Aedes aegypti is the predominant species found in Mojokerto region, 2012, this species still plays an important role for the outbreak of DHF. Aedes aegypti has an Importance Value Index (IVI) of 70.48\%. The Morisita index shows that the pattern of spread of mosquitoes in the Mojokerto district is uniform. The elevation of area and density of mosquitoes has a positive association.

\section{ACKNOWLEDGEMENTS}

The authors are grateful for the financial support of the Directorate General of Higher Education (DGHE) scholarship batch $5^{\text {th }} 2011$ from Indonesia government and grant from the Global Environment Leaders (GELs) program, Graduate School for International Development and Cooperation (IDEC), Hiroshima University, Japan.

\section{REFERENCES}

[1] Hopp, M.J. and Jonathan, A.F. (2003) World wide fluctuations in dengue fever cases related to climate variability. Climate Research, 25, 85-94. http://dx.doi.org/10.3354/cr025085
[2] Herrera-Martinez, A.D. and Alfonso, J.R. (2010) Potential influence of climate variability on dengue incidence registered in a western pediatric hospital of Venezuela. Tropical Biomedicine, 27, 280-286.

[3] Abdalmagid, M.A. and Alhusein, S.H. (2008) Entomological investigation of Aedes aegypti in Kassala and Elgadarief States, Sudan. Sudanese Journal Public Health, 3, 77-80.

[4] Zulfaidah, P.G. and Nobukazu, N. (2013) Climatic variability and dengue hemorrhagic fever incidence in Nganjuk district, East Java Indonesia. Acta Biologica Malaysiana, 2, 31-39.

[5] Schmidt, W.P., Motoi, S., Vu D.T., Richard, G.W., Ataru, T., Lay-Myint, Y., Hideki, Y., Ubydul H., Le H.T., Dang, D.A. and Koya A. (2011) Population density, water supply, and the risk of dengue fever in Vietnam: Cohort study and spatial analysis. PLOS Medicine, 8, 1-10. http://dx.doi.org/10.1371/journal.pmed.1001082

[6] Hopp, M.J. and Jonathan, A.F. (2001) Global-scale relationship between climatic and the dengue fever vector, Aedes aegypti. Climatic Change, 48, 441-463. http://dx.doi.org/10.1023/A:1010717502442

[7] Health Department of Indonesia (2005) Prevention and eradication of dengue fever in Indonesia. Health Department of Indonesia, Jakarta. (in Bahasa)

[8] Morisita, M. (1959) Measuring of the dispersion and analysis of distribution patterns. Memories of the Faculty of Science, Kyushu University. Series E: Biology, 2, 215235.

[9] BPS (2010) East Java Province in figure. Central Statistical Agency in East Java Province, Indonesia. (in Bahasa)

[10] Leisnham, P.T., David, P.S., Philip, J.L. and Philip, W. (2005) Evaluation of two dipping methods for sampling immature Culex and Ochlerotatus mosquitoes (Diptera: Culicidae) from artificial containers. New Zealand Journal of Marine and Freshwater Research, 39, 1233-1241. http://dx.doi.org/10.1080/00288330.2005.9517389

[11] Wolda, H. (1981) Similarity indices, sample size and diversity. Oecologia, 50, 296-302. http://dx.doi.org/10.1007/BF00344966

[12] Budiyanto, A. (2012) Relationship between characteristics of containers to abundance of Aedes aegypti larvae in the Elementary School. Journal of Pembangunan Manusia, 6, 1. (in Bahasa)

[13] Basiri, R., Seyyed, A.T. and Hamid, B. (2011) Statistical analysis of spatial distribution pattern for five tress species in Kurdestan Region. World Journal of Science and Technology, 1, 36-42.

[14] BMKG Malang City (2013) Climate data of Mojokerto region on January. BMKG Malang City, Malang. (in Bahasa)

[15] Devi, N.P. and Jauhari, R.K. (2004) Altitudinal distribution of mosquitoes in mountainous area of Garhwal region: Part I. Journal of Vector Borne Disease, 41, 17-26. 